\title{
LITERARY SOCIETIES AND MODERNISM: THE SOCIAL COMPOSITION OF THE KAZINCZY CIRCLE IN KASSA AT THE TURN OF THE CENTURY
}

\author{
PÁL KOUDELA \\ Kodolányi János University \\ pkoudela@yahoo.com
}

\begin{abstract}
Literary societies are in focus both of literary studies and social history. ${ }^{1}$ In particular, they played an important role in the modernization of Central Europe in the $19^{\text {th }}$ century. Becoming widespread in this era, they helped develop a democratic ${ }^{2}$ political culture and disseminated literature to a wider audience. Hungarian historiography has depicted this period as one of large-scale social segregation and a fragmented middle class which refused to have any contact with the bourgeoisie, ${ }^{34}$ while Slovakian historians have emphasized the exclusion of Slovaks from elite society. ${ }^{5}$ Kassa (today Košice), which was then situated in northern Hungary and is now the largest city in eastern Slovakia, has, however, been recognized as a more complicated example that challenges these assumptions. ${ }^{6}$ For instance, the importance of local citizenry was preserved in the first half of the $19^{\text {th }}$ century, in contrary to other cities in Hungary. ${ }^{7}$ The purpose of this article is to examine the composition of the most prominent social club of the town to provide fresh insights into the social history of Kassa in this period, and the larger processes shaping urban life in Central Europe in the period before the First World War. In particular, this article argues that a culture of both pluralism and exclusion was evident in the membership of Kassa's Kazinczy Circle, and that their affiliations reveal a more complicated social network in the city, which both preserved communal solidarity during a period of rapid urbanization and encouraged the growth of modern democratic values.
\end{abstract}

Keywords: literary societies, Hungarian social history, $19^{\text {th }}$ century history, middle class, Kazinczy Circle, modernization

\section{What social exclusion in associations represents on a wider social scale}

Kassa (today Košice) has always received significant attention from historians and literary critics interested in its culture, history and social transformation. Its intellectual life, theatres, pluralistic ethos and multicultural population have continuously inspired researchers to explore the reasons for its distinctiveness. It became, for example, the European Capital of Culture in 2013, has the largest gothic cathedral in Central Europe and had an outstanding role in both Hungarian 
and Slovak cultural history - for instance Bánk Bán, ${ }^{8}$ the famous Hungarian play with nationalistic overtones made its debut there in 1833 , or we can mention that Sándor Márai was born in Kassa. In addition, the city has long been celebrated by historians for its tolerance and community cohesion. ${ }^{9}$ These virtues had extremely high importance both in the age of dualism, when Hungary was wrestling with its multi-ethnic character, ${ }^{10}$ and between the two world wars, when ethnic nationalism continued to shape the Czechoslovak Republic.

Rooted in the late middle ages, literary societies had been widespread in almost every town and city of Europe ever since the first such circles appeared in Normandy and London. Late medieval companies and their successors specializing in literary culture were part of the European corporate tradition. ${ }^{11}$ From the second half of the $19^{\text {th }}$ century onwards, civil society flourished in Europe and began to do so in Hungary, too. ${ }^{12}$ Hundreds of associations came into being in towns, counties and even on a national scale. Their activities were multifarious: different covenants, leagues and societies dealt with advocacy, aiding and social care, health, social life, industrial and commercial life, education, the cultural sphere or even with politics and public affairs. Cultural organizations formed a narrower group (public education associations, choirs, social circles, sports and tourist clubs, reading circles and educational societies), and started to spread at the beginning of the $19^{\text {th }}$ century. This kind was, probably, the most widespread among associations, contributing to the institutionalisation of the non-advocacy civic sphere. The construction of these societies was based on a wide social scale, and became inextricably interwoven with contemporary everyday life itself, having a beneficial effect on complex social developmental processes. At the same time, their organisational structure (general assembly - committee - officer corps) had the power to mediate a democratic political culture toward civic society. In the case of Kassa, contemporary observers distinguished three types of societies: social, cultural and charitable. ${ }^{13}$ The key rules governing these associations were laid down in the regulation No. 1508/1875 of the Ministry of Interior, which reflected the overall socio-political inequality of the system by discriminating against minority and workers' organizations. For example, the cultivation of Slavic culture by the premier Slovak cultural organization, Matica slovenská, was condemned for promoting panslavism, and was banned by the Hungarian government in $1875 .{ }^{14}$

Voluntary associations had an important role in the development of Slovak society. The formation of civil society went hand in hand with political, demographic and social developments. By 1918 there were several associations in northern Hungary, however, only some of them were Slovak, and their activities were rather informal, since they were strictly supervised. ${ }^{15}$ For this reason, examining the ways of exclusion affecting existing cultural societies, or particular groups within such societies, is extremely important. In this study we focus on Kassa 
at the turn of the century - a local society which has been often characterized as rigid, fragmented, feudalistic and divided. ${ }^{16}$

Nevertheless, although civil society was beginning to emerge in northern Hungary in the decades before 1918, the Kazinczy Circle was very active in striving to elevate Kassa's cultural life to a higher standard and to enhance its reputation in Hungary. For example, the circle arranged for memorial plaques and invited nationally renowned personalities to visit or elected them as honorary members. This particular circle unveiled the memorial plaque to Ferenc Kazinczy in 1901, ${ }^{17}$ elected the prominent writer Kálmán Mikszáth as an honorary member in 1909 and another leading writer Zsigmond Móricz gave lectures to them in 1914. ${ }^{18}$ They also represented the city on the national level, for example representatives of the circle attended various ceremonies both in Kassa and elsewhere in Hungary. ${ }^{19}$ This article focuses particularly on the circle's ethos and the plurality of its membership.

Literary societies, like many other associations in Hungary at this time, were usually affiliated with an organisation, a university for instance, and as a consequence their membership was limited accordingly. Many literary societies existed in other towns, like the Csokonai Circle in Debrecen (1890), the Dugonics Circle in Szeged (1892), the Szigligeti Circle in Nagyvárad (today Oradea) (1892), the Toldy Circle in Pozsony (today Bratislava) (1874), the Kölcsey Circle in Arad (today Arad in Romania) 1881, the Jókai Circle in Pápa (1892), the Frankenburg Circle in Sopron (1877) or the Széchenyi Circle in Eperjes (today Prešov) (1878). ${ }^{20}$ In other cases, they functioned as elite social circles. While from an occupational point of view their composition was mixed, they were fundamentally recruited from the same social segments of the local societies. For example, the Literary Society of Washington, which was founded in 1874, had a membership that came from the elites of the city including the leading intellectuals of the contemporary United States, some of whom had also been the founding members of the Cosmos Club, an elite private society. ${ }^{21}$ It is also remarkable that this society was founded in the American capital, which had a population at that time of 131,000 , but only consisted of 24 founding members, which increased to forty in the following years. (In addition, for its first 110 years, the Cosmos Club did not permit women members.) Likewise, in 1888 in Berlin, with a population of one and half million, the Literarische Gesellschaft was founded by only 99 members. Similarly, in 1901 in Kassel, Germany, with a population of 100.000, a literary society was set up called Freie Feder. Its goals were similar to those of the Kazinczy Circle: having been a gentlemen's association it was created to support the dissemination of literature by promoting public readings. This group in Kassel was neither a professional association of interests nor did it serve economic purposes. Members were amateur literary patrons, most of them public service employees, lawyers or teachers, however, based on their occupation, they definitely 
belonged to the small intellectual elite of the city.22 (Unfortunately Wülfing does not mention the number of members.) In contrary, Kassa had only 22,000 inhabitants when its literary society was established in 1898 but it was founded by 197 people, which soon rose to 201 including twelve female members. This fact also gives a special character to this elite society.

Regarding the multiple social divisions in Hungary during the age of dualism - whether ethnic, religious fractures or the particular contrast between the state employed middle class and the capitalist bourgeoisie society (according to the distinction described earlier) - the development of civic society was a major factor in modernization, fostering social cohesion. ${ }^{23}$ Hungary - including today's Slovakia that comprised the north of kingdom - had large numbers of minorities. Some of them, such as the Jews, became part of the middle classes, while others were excluded. Most importantly, the use of the Hungarian language was a means of integration but also assimilation that divided society in two. One important consequence was the lack of Slovak intellectuals. ${ }^{24}$ At the beginning of the First Czechoslovak Republic, to fill up the missing positions in offices, schools and many offices of governance (since in 1918 following the dismantling of the kingdom, many officials fled to rump Hungary) the new government had to recruit Czech employees. ${ }^{25}$

On the other hand, the limitations on Slovak national and cultural activities in Hungary during the nineteenth century contributed to a new Slovak activism. ${ }^{26}$ Andrei Radlinský collected signatures for the use of the Slovak language, and Jozef Miloslav Hurban drafted the Slovak National Memorandum. Because the official use of the Slovak language remained prohibited - especially at the higher levels of administration, where the senior administration was required to use Hungarian, while notaries frequently used Slovak, as did many priests -, leading personalities of the Slovak minority organized a national gathering in Turócszentmárton (today Martin) on 6-7 June 1861. In front of an audience of 5.000, they proclaimed their political program, the Slovak National Memorandum, with great enthusiasm. As a result of the repression, Slovak national movements became increasingly strong. The situation worsened with the language law adopted by Count Albert Apponyi in 1907 which incentivized even independent schools to reduce their Slovak language teaching. In the period until the first world war tension between Slovak and Hungarian ethnicities was fueled by occasional brutality and judicial repression. ${ }^{27}$

During the last decades before the First World War a large amount of miscomprehension aggravated the situation. The partial exclusion of Slovaks from the process of modernization - i.e. the growing importance of the middle classes also reinforced ethnic divisions. The larger purpose of this article is to reassess these social dynamics by appraising a prominent literary society. To create a more 
accurate picture about the importance of the Kazinczy Circle and other similar societies, to describe their activities, events and inner structure is not enough; the exact composition of its membership also needs to be carefully examined. We need to explore to what extent this was a genuinely open and integrating society, and to what extent distinct social groups were forged together by their common interest in cultural issues.

The activity of societies in Slovakia in the period before 1918 is described in detail in the compilation Cultural and Educational Work in Slovakia in 19011918, edited by Michal Potemra. ${ }^{28}$ Elena Mannová focuses her research primarily on the social history of voluntary associations in the $19^{\text {th }}$ and $20^{\text {th }}$ centuries. In her dissertation, entitled Societies and Their Place in the Life of Society in Slovakia in the $19^{\text {th }}$ and $20^{\text {th }}$ Centuries, she devotes her attention to the genesis and development of the associations scene from the beginning of the $19^{\text {th }}$ century to the mid-20 $0^{\text {th }}$ century. In numerous published studies she monitors the impact of political changes on the life of the society, but without closer specification of the activities of associations. ${ }^{29}$

\section{Town and region}

Kassa was the second largest city in northern Hungary during the Habsburg Monarchy and has preserved this position in present-day Slovakia. The municipality and the surrounding region developed in a specific way both in terms of the economy, policy and society, particularly since the country split into three parts in 1541 . In the early modern period, however, progress came to a standstill, ${ }^{30}$ and a long period of stagnation began, while certain archaic conditions persisted until the beginning of the $20^{\text {th }}$ century. As a consequence of this specific development, an exceptional role and significance is regularly attributed to the town. Kassa became a royal free city in 1347 (some rights, like the free election of priests and judges, were already guaranteed in 1249 by Béla IV) and received numerous privileges thenceforward: for example, tax exemptions and the right of stopping goods in transit were granted by Louis I of Hungary, Sigismund and Matthias I. ${ }^{31}$ Most towns and cities in Upper Hungary sustained their status in a functional sense throughout the $18^{\text {th }}$ century, preserved their original privileges or even received newer ones - e.g. mining towns were rewarded because of their important role in the economy, while Kassa also retained its privileged position. ${ }^{32}$ After the revolution of 1848 , the reform of civil administration and improvements in the manufacturing industry fostered urban development and embourgeoisement. Nevertheless, municipalities remained small towns in Upper Hungary until the beginning of the $20^{\text {th }}$ century, or even declined, while their functional structure ossified. 
This region certainly developed more slowly than other parts of the country. The entrepreneurial bourgeoisie had a much smaller role in the economy compared to the role that this social group had played in the eighteenth century. The overall composition of the population also continued to be dominated by artisans, winegrowers, landowners and intellectuals, as had been the case since the medieval period. Kassa's situation was, however, unusual because it was both a religious and cultural centre and a centre of the government administration. ${ }^{33}$ In northern Hungary, however, the smallest market towns gained and preserved numerous privileges,${ }^{34}$ but these rights had become by the nineteenth century a source of prestige rather than providing real economic or social advantages. Pozsony (Bratislava) was the one obvious success story in the region. Due to its closeness to and economic relations with Vienna, Pozsony, a former capital of Hungary, developed faster than any other urban centre in northern Hungary and gradually detached itself from the lagging Upper Hungary region.

Nevertheless, there are other reasons why Kassa was assumed to be the ideal place for research. Besides its medium size there are characteristics which set it apart from other towns in the region. First, its level of development distinguished it from surrounding Abaúj-Torna County. Kassa was an isolated centre of modernization, as the county's development significantly lagged behind the city, as well as behind the average of the wider region. ${ }^{35}$ On the other hand, we find a more complex causation system. The eighteen counties of Upper Hungary can be divided into well-defined sub regions before 1918 with regards to historical, cultural and economic considerations, as well as the differences in ethnic composition. All of these aspects influenced the behaviour, values and manners of the people living there and interacting with each other. The ethos of the western territories was fairly unique: Pozsony and Nagyszombat (Trnava) could be characterized by a peaceful, constructive, bourgeois idyll, which was rather similar to some particular areas of Germany. The northern counties, Árva, Trencsén and Túróc were distinctive, having been a longstanding centre of Slovak cultural life and were dominated by a rural population. Much of Szepes County was, however, distinct and isolated because the inhabitants - referred to as 'cipszer' after the borough's German name, Zips - preserved their characteristic, self-contained culture, German language and independent legal system until the eighteenth century. Although towns in this area flourished commercially, as a result of their distinct culture, they were never integrated into the wider regional economy.

In contrast, Sáros County was under Polish and Hungarian influence, inhabitants, despite being largely settled in towns, still lived like the gentry, while the mining towns further west also retained their own distinct culture. Kassa and the whole of Abaúj County were also unique compared to all of the other sub-regions of northern Hungary, as this was a particularly heterogeneous area. Kassa was 
neither simply German, nor Hungarian, neither predominantly bourgeois (capitalist) or dominated by the middle classes (state officials). It can be characterized by the diligent work of the German 'Bürgertum', as well as by fervent Hungarian patriotism. In the surroundings of Kassa there were German settlements (e.g. Mecenzéf/Metzenseifen, Stósz/Stooß - today Medzev and Štós) but also Slovak-speaking villages whose inhabitants gradually moved to Kassa, enriching the city with their own Slovak culture.

Coexistence therefore had a longstanding tradition in Kassa. As a consequence, culture was more multifarious, and more pluralistic. Germans, Slovaks, Rusyns and Hungarians lived in this town together with a reasonably large Jewish community. ${ }^{36}$ As Pál Szvatkó observed, 'Vienna's attraction cannot be felt, contrary to Pozsony, and Budapest's influence was rather new-fangled. The citizens of Kassa, of whom many became Hungarian only a couple of decades earlier, inherited their tenacity and collective feelings from Saxons, gained their enthusiasm from Hungarians, and obtained a soft mediocrity of forms and some frivolity from the Slavs. ${ }^{37}$

Multicultural society can facilitate the development of urban modernity, especially the transformation from early modern civic values. A typical element of this transformation was the process by which the citizenry of privileged towns became a capitalist bourgeoisie. Many towns, through institutions such as the guilds, had been at pains to exclude newcomers and preserved a greater degree of homogeneity as a consequence. Such retrograde behaviour of the 'old' citizenry conserved their value system. In a more heterogeneous society the acceptance of a new bourgeoisie was easier. However, differences in the development of towns cannot be attributed merely to differences between 'old' and 'new' civic values: both of them emphasized performance-based work, diligence, dutifulness, and honoured knowledge. The belief that good quality in work ensured the future of children through education and the family's well-being, was characteristic of urban settlements throughout northern Hungary. ${ }^{38}$ Kassa conformed to elements of both the older and newer civic culture that it preserved, as it benefitted from a certain degree of modernism and economic progress, but also retained a more archaic middle-class based social structure.

A good example of the unique identity that developed in Kassa, and the local patriotism that existed there, is revealed by an old man, who was interviewed by Éva Kovács after 1945. He declared, 'I'm not Hungarian, because otherwise they would have deported me, and I'm not Slovak, because then I would also have been deported. If I was Jew, Israel would be my place - what else could I be but a Kassa man? ${ }^{39}$ Middle class society was more plural in Kassa at the turn of the century than in similar sized towns in other regions of Hungary; different groups within the middle class were less segregated and separated. This hypothesis is best verified by examining their social networks. 


\section{The middle class}

As István Weis has observed about Hungarian society, 'the middle class is the most difficult to define or elaborate of all social strata'.$^{40}$ It is thus most important to define the central concept of the inquiry: the middle class. In England, alongside the two dominant characteristics - the scale of owned property and the extent of access to power ${ }^{41}$ - denominational and especially educational background became influential features ascribed to the middle class. ${ }^{42}$ Derived from French and Italian micro-history, a sociological approach is also relevant. To define the nineteenth century middle class properly, the identification of the different occupational groups is a very important aspect. We can more easily explore social fragmentation by distinguishing between the narrow social groups that combined to make up the middle class. ${ }^{43}$ This analytical approach reveals the integrity of middle-class society, and reveals the role of urban institutions and lifestyles in addition to economic characteristics. Although including civic values in the definition of the middle class is important, especially its critical role in fostering modernization, particular lifestyles can also be considered as a consequence of the quality of life and a representation of one's social position.

To interpret middle-class structures in Central Europe, the traditional model of industrialization and its core idea that the importance of craftsmen, artisans and small entrepreneurs was diminished by the expansion of large companies, cannot be applied. ${ }^{44}$ It would also be misleading to interpret the emergence of the middle classes in this region to the rise of service occupations, which characterize post-industrial societies. In contrast to Western European societies, industrialization was not the most important determining factor in Central Europe in the $19^{\text {th }}$ century. Central Europe accordingly needs alternative interpretational approaches, for example by analysing contemporary societies through specific local communities and associations. This article, therefore, applies the flexible approach advocated by Ferenc Erdei ${ }^{45}$. Erdei found that Hungarian society was divided into two distinct groups: one composed of artisans and businessmen all the way up to the wealthy capitalists (this is what we shall refer to as the bourgeoisie), and another composed of state officials and landowners (referred to as the middle class). During the communist period, a distinction continued to be drawn by historians between the 'noble order' and the Jewish bourgeoisie, and since the 1970s this has been used in most cases in accordance with Erdei's concept. Szekfü's own work did not focus on the Jewish bourgeoisie, ${ }^{46}$ but he did argue that the Hungarian population outside the capital city lived in isolated groups, and noble and non-noble society did not interact.

Among Slovak historians ${ }^{47}$ it seems clear that there is no widely accepted definition of the middle class. The issue of studying the aforementioned component of the population, whether in terms of its existence as a social group in the social- 
ly differentiated community of the city, or from the aspect of the bourgeois way of life (culture, norms and values, traditions and so on), has been circumvented in the past by social scientists in Slovakia. Over the past fifty years, these disciplines have focused on the study of history, the way of life and the traditions of the working classes of rural and working-class communities. The subject of research was related to the ideological demands of the time and the need to explore those social communities that exhibited national or folk traditions. ${ }^{48}$ After 1989 , social scientists in Slovakia focused on the middle class from the perspective of modernization, nationalism or civil society. In the late 1990s, interdisciplinary projects were developed involving sociologists, ethnologists, historians, literary scientists and political scientists - in particular Bourgeoisie and Civil Society in Slovakia 1900-1989 edited by Elena Mannova in $1998^{49}$ which outlines a wide range of sub-issues related to the life of this component of the population.

The original 'bene possessionati' lower nobility's transformation into the gentry, later into the middle class and finally into professional intellectuals ${ }^{50}$ over generations was discussed in István Bibó's analysis of the survival of archaism. This concept, however, cannot be confirmed genealogically. The gentry middle class was largely composed of public officials at the turn of the century, however, three quarters of them didn't have noble ancestry, ${ }^{51}$ and in the Horthy era the proportion of nobles in these middle class positions further decreased. Some kind of feudalistic exclusiveness, nevertheless, characterised this strata: the highborn core of the occupational group made entry almost impossible for retailers and other members of the petite bourgeoisie, including those whose incomes had increased significantly. (Bibó, for example, still complained about this phenomenon in the 1940s.) The gentry segment of the middle class is, therefore, exceptionally important due to its influence on broader society.

A more persuasive starting point for defining the middle class in Kassa is the work of Gábor Gyáni. ${ }^{52}$ Middle class and bourgeoisie dimensions are separated in his scheme - following the original insight by Erdei - but a third element is added: that of non-public or market-oriented intellectuals. Although Gyáni's definitions were initially applied to Hungary in the era between the two world wars, the aspects he highlighted also perfectly fit the political-social environment at the turn of the century. Indeed, the fundamentals of Hungarian society in the 1920s and 1930s were rooted in the former Austro-Hungarian Dual Monarchy.

Nevertheless, the most detailed analysis of the middle classes can be found in Gyáni's argumentation. Gyáni builds on earlier research on artisans, primarily skilled manual self-employed individuals and provides a framework for understanding this class. These jobs were still important in the first half of the $19^{\text {th }}$ century. By mid-century, however, research has emphasized the growth of smallscale capitalism and the spread of retail. ${ }^{53}$ Along with them clerical, technical, and managerial workers entered the middle class in the late $19^{\text {th }}$ century and early $20^{\text {th }}$ 
century. ${ }^{54}$ At the same time the exclusion of the petite bourgeoisie business owners from the middle classes became prevalent in historiography ${ }_{.5}^{55}$ In contrast, this article argued that the middle class was a remarkably heterogeneous social group which is best analysed through empirical evidence instead of a deductive model.

Gábor Gyáni has provided a sophisticated, versatile and diversified portrayal of the middle class of this period. For example, he observes that civil servants - the first branch in his classification - cannot be considered in the same social class as even the lowest rank of the nobility (the gentry). Housing statistics confirm that the three-bedroom minimum requirement to belong to the middle class was not widespread enough. This prerequisite was explicitly articulated during the last decades of the $19^{\text {th }}$ century in published guides written for the middle classes. These handbooks provided advice on everyday life in Budapest and formulated social expectations. ${ }^{56}$ One of them was the minimum size of apartments even though this expectation was not always matched by actual living conditions. At the same time, identity as determined by public employment was weakening, due to the dilution of this social group's prestige by the growing participation of women in traditional middle class jobs and the decreasing number of nobles in these positions..$^{57}$

The concept of the bourgeoisie, the second branch according to Gyáni's division, consisted of middle-scale traders, artisans and private officials. In addition, when describing social groups religious affiliation had a special role, especially as regards Hungary's Jewish communities which were mostly urbanized, but also isolated and excluded from other parts of middle class society. This duality appears in most analyses produced both in the period and today, and was already described in Szekfü's previously mentioned monograph, also cited by Gyáni. ${ }^{58}$ Applying both income and the number of employees as criteria is rather difficult in the light of the vast differences between the dominant capital city, Budapest, and other, much smaller towns of the era. In the case of either traders or private officials, similar incomes could provide a very different financial situation and lifestyle in a small town of the countryside compared to Budapest. This was in contrast to public officials for whom such differences were, in some ways, compensated by the state. In Budapest a branch manager of a bank, for example, hardly belonged to the middle class, while in a tiny municipality he was definitely a member of this class.

The third branch of the middle classes in Hungary in this period, in Gyáni's model, was comprised of intellectuals with university or college degrees, who were not employed by the state. Lawyers, doctors, pharmacists, journalists, artist and actors can thus be described as market-oriented professionals. There was a gradual increase in the size of this group during the second half of the nineteenth and the first half of the twentieth centuries. Many drifted to such careers after finding it difficult to compete for positions in the already overcrowded nation- 
al and local government institutions. This stratum was also heterogeneous and sharply divided by religious affiliation.

In summary, the middle class in late nineteenth century Hungary was remarkably heterogeneous, undergoing a process of complicated transformation, and is exceptionally difficult to define. Moreover, in specific cases such as Kassa, a local ethos also influenced the membership of the middle class in this city. We will, therefore, use the term 'middle class' to define a status group rather than a class structure that conforms to the Weberian social structure, where classes and status groups are distinct albeit overlapping categories within society, and social esteem is indicated more clearly by privileges based on manners, formal training and the prestige of professions and ancestry. ${ }^{59}$

Finally, we have to mention that the distinction drawn between the 'old' citizenry, based upon its legal status, and the new heterogeneous bourgeoisie is a new phenomenon in Hungarian historiography. Traditionally the two terms were considered synonymous, while, at the same time, discontinuities between the old and the new bourgeoisie were emphasized. According to Vera Bácskai there were several reasons for this confusion: on the one hand, most of the historians concentrated on the upper middle classes, which included only a few former members of the urban population in the $19^{\text {th }}$ century. On the other hand, the 'foreign' origins (mostly German and Jewish) of the urban population meant that they were not properly interpreted as part of the changing middle classes but were instead described as simply alien. ${ }^{60}$ In addition, comparisons with Western Europe led to the Hungarian middle class being unfairly considered as archaic.

\section{Kassa's social complex in the 19th century}

The social structure of Kassa's population, therefore, did not change fundamentally until 1918, and could hardly be characterized by modern class structures. Its inhabitants' position in society was determined by the specific prestige of their occupation and income, an attitude that can be traced back to the occupational composition and social architecture before 1848, when citizenship in Hungarian towns had been a distinct legal category. Namely, the burghers of Kassa were a social group which actually existed in legal terms before 1848 , to which benefits and privileges were connected. In that period burghers enjoyed collective advantages of tax exemption, the storing of goods and many other advantages. Indeed, even a nobleman considered it worthwhile to be entitled to the status of burgher, even if he enjoyed other privileges. In the first half of the $19^{\text {th }}$ century Kassa was not one of the declining (mining) towns of northern Hungary. While, for instance, in Selmecbánya ${ }^{61}$ (Banská Štiavnica) less and less silver was mined, Kassa remained the unofficial capital of the region according to Pál Magda and Elek Fényes, ${ }^{62}$ and foreign travellers had 
the same view. ${ }^{63}$ Kassa was regarded as pleasant, its shops and citizens were seen as rich, its aesthetic quality and the large numbers of administrative and cultural buildings were often emphasized. The town was exceptionally suitable for a bourgeois lifestyle: it had a vivid theatre life, casinos, coffee houses and promenades - and thus Kassa rivalled Buda and Pest regarding its social life. ${ }^{64}$ During the Reform Era Kassa was ranked as the fourth most important city in the national rankings. ${ }^{65}$

After the 1848 revolution, and the abolition of feudalism its privileges were ended and a more consistent and democratic situation developed. The benefits and disadvantages of urban life affected all of its inhabitants equally. Nevertheless, a social group or unit very similar in composition to the former burghers of Kassa before the Revolution, endured in this period. Many merchants and officials counted as 'real burghers'; furthermore, noblemen also identified themselves as part of this group. Nevertheless, not every merchant or official became a member of this social core, as such identification was not derived merely from one's occupation. Both before and after 1848, civil status was dependent not only on a person's economical and official importance, and gaining such a status depended not only on financial and legal prerequisites. In addition, the highly elusive aspect of prestige was a key factor in determining membership in Kassa's social elite, for example, participation in civil organizations and the place of residence also played a significant role. A merchant deserved an entitled position partly due to the rate of his income and partly due to the nature of his activity, namely how far it was appreciated by the local community. Occupations carried an attributed quality, based both on traditional local values, as well as on financial or legal advantages.

Officially, the number of burghers in Kassa was 637 in 1842, only $5.7 \%$ of the whole population of the town; they were teachers, lawyers, retailers, merchants, traders, as well as counts ${ }^{66}$ such as, for instance, Tivadar Csáky, Ferenc Dessewffy and Manó Péchy ${ }^{67}$ It was not only a legal category, but a tight relationship too, as their economic conditions were similar (according to the amount of tax they paid), and their connections to the town were multifaceted and far stronger than their fellow inhabitants'. According to the local regulations and statutes, only they could fulfil municipal positions, they could represent the city at special events, they had the right to trade, operate local business and guilds, ${ }^{68}$ and only they had the wealth to support (and enjoy) cultural life. In the first half of the nineteenth century, becoming a burgher was about joining a local elite rather than a practical question. Kassa was different to Pest in terms of the surviving traditional order, and local patriotism was more intense. (In other parts of Hungary the importance of local citizenry decreased and the role of their civic code became eroded. ${ }^{69}$ ) It happened partly because of the much smaller population of Kassa, compared to Hungary's capital, and consequently the smaller size of is social elite. This is not, however, the only explanation for this phenomenon. It was also the result of the fact that in Kassa modernization, or more narrowly embourgeoisement, happened within the 
framework of a specific feudal social order, which was structurally preserved while also being reorganized from within. ${ }^{70}$ Social networks did not change even after feudalism was formally swept away. For example, the membership of local freemasonry lodges remained the same throughout the nineteenth century, with professors, physicians, solicitors, some county noblemen and even retailers working together. Prominent personalities such as count Lajos Török and Ferenc Kazinczy also became members of the lodges in order to participate in this social elite. ${ }^{71}$

Even after 1848 a person's origins continued to matter. The 'real burghers' of Kassa derived their membership in this category from their grandparents who had earned this privilege, but they also had to earn the right to maintain this status. Charitable bequests and membership in civil organizations which they themselves established were also required. Kassa had 57 associations at the end of the $19^{\text {th }}$ century: 19 social associations, 15 public educational associations aimed at literature, arts, sciences, and self-education, and 23 charitable associations. ${ }^{72}$ During the second half of the $19^{\text {th }}$ century, however, Slovaks had no associations at all of their own yet. ${ }^{73}$

The Kazinczy Circle, founded in $1898,{ }^{74}$ was the $58^{\text {th }}$ association to be established in Kassa. Among its 41 managerial and council members between 1916 and 1919 were 18 teachers, 7 church dignitaries and pastors, 11 state or municipal officials, archive or museum directors, 3 private officials and lawyers, as well as 2 retailers. ${ }^{75}$ If we include full and supporting members of the society we obtain a more mixed picture. For example, from the list of council members, Ignác Czigler was a history and geography teacher in the State Upper and Finishing School, who - after 34 years of service - earned 4400 crowns $^{76}$ annually and a sum of 1200 crowns was awarded to him as a pension. ${ }^{77}$ At the same time Engelbert Mázy - another council member in the circle -, who was the chief executive of the school board of Kassa, earned 12000 crowns annually; ${ }^{78}$ while another member of the circle Géza Grosschmid ${ }^{79}$, one of the most successful lawyers in contemporary Kassa, was even more prosperous.

It is useful to compare the membership of the Kazinczy Circle to a similar association in Kassa, the First Hungarian Choral Club of Kassa (Kassai Elsö Magyar Dalegylet), established in 1867. Its founders included a senior official at the Mortgage Bank of Kassa (Kassai Jelzálogbank), a choirmaster, a forensic clerk, a financial official, the deputy city notary, a lawyer, a teacher from a public elementary school, a city bailiff, a factory official and count Albin Csáky. ${ }^{80} \mathrm{Kas}-$ sa is certainly not unique in showing that older social networks survived in the new associations. In the wider region other municipalities preserved similar patterns, ${ }^{81}$ however, Kassa's exceptional economic and cultural position exemplifies the diversity of these older social networks. Retailer and innkeeper sung together with landed gentlemen, private and state officials or intellectuals. Similar social patterns can also be recognized in the spatial order. For example, an analysis of 
the names and occupations of house owners or even residents in Main, Mészáros or Kovács streets in the city centre and a comparison with dwellers living on the outskirts indicates that even in its spatial geography Kassa retained its pre-industrial social divisions during a period of rapid urbanization in the second half of the nineteenth century, and the turn of the century. For example, $75.4 \%$ of the 183 teachers lived in the historical centre of the city in 1906 . Teachers were surely members of the middle class, but still unaffected by the emerging urban sprawl in Kassa - both them and the Ring preserved its earlier symbolic value. ${ }^{82}$

Sociologist Ján Pašiak characterizes the bourgeoisie through categories such as ownership, education, living standard and cultural level, some forms of social contacts and the resulting urban lifestyle. ${ }^{83}$ Another distinctive feature is the lifestyle that distinguishes the group from the rest of the city's population: the location of a house in the city center along with a certain type of architecture, stylishly furnished spacious interiors, sanitary facilities, electricity, water and so on. ${ }^{84}$ In cities like Kassa geographic zones had an exceptional role, especially in relation to habitus and class, defined by Bourdieu as social spaces..$^{85}$ Local institutions reproduced this local ethos, where institutions reflect not just educational or legal distinctions, but also material and communal symbols and segmentation. The centre of the town, where the burghers had formerly concentrated, retained its outstanding cultural role, even if the structure of Kassa's social spaces was transformed during this period, resulting in small-scale suburbanization and the dominance of the petty bourgeoisie in some districts.

To define a specific community in Kassa, it is more effective to focus not on cultural markers such as linguistic or dialect differences but rather to consider spatial geography and social segregation, the presence of pluralism, greater tolerance and interrelated, permeable classes. The local community absorbed the German citizenry (we can read about them in Márai's novels). Of the 14759 persons who changed their original names to a Hungarian name between 1800 and 1893 no fewer than 5539 were German. ${ }^{86}$ This is the largest part among all ethnicities and exceeds by far the rate of the German minority in contemporary Hungarian society. ${ }^{87}$ Jews played the leading role from the viewpoint of Magyar nationalism, ${ }^{88}$ and the multilingual character of the community persisted in Kassa during the whole era ${ }^{89}$ Even after the turmoil of 1918-1919 and the integration of Kassa into the newly formed Czechoslovak Republic, Slovaks, Hungarians, Jews, as well as recently immigrated Czechs, preserved their old social networks or created new ones. ${ }^{90}$

\section{The Kazinczy Circle as melting pot}

The membership list of the Kazinczy Circle represents how the new middle class structures became embedded in the specific local culture. Although many other social associations existed in Kassa simultaneously, none of them had exactly 
the same character, while membership in multiple associations was not excluded either. We can also measure the plurality of the middle class in Kassa at the turn of the century by examining the occupational composition of the membership of the most eminent social association in the city, the Kazinczy Circle. ${ }^{91}$

To find interactive and open relations we looked for a place of everyday use, where such activity could and was expected to happen. The Kazinczy Circle was precisely such a location, where the promotion of culture and science was not just a demonstration of social standing and values. This association was not only a place where members could exhibit their contribution to public life or display their wealth with donations - it also served as a club in its original meaning to which no one could belong unless they were accepted by the standards of the unwritten laws of the wider society. Most events of the Kazinczy Circle were not intended for a wider audience, many occasions were deliberately small and designed to create a friendly atmosphere. This in no way means that participants at a club meeting or public reading, or users of the club library were all friends, but for mundane life these places served to maintain relationships. Members visited the club regularly since its formation was not only for administrative purposes but also to meet and talk to each other. It was merely a location that created an exceptionally sociopetal space. ${ }^{92}$ In addition, documents and correspondence compiled by Ferenc Sziklay - an executive of the association - reveals the close relationships maintained by members of the circle as they existed outside the society's premises. For example, Sziklay himself, when lost his job as a teacher in 1919, had to find livelihood. First he became an assistant electrician, later to start a political career. In both cases, the people who helped him were members of the society - including his father-in-law. ${ }^{93}$

The transformation of literary life initiated by Ferencz Kazinczy, Dávid Baróti Szabó and József Batsányi in 1786, which took the form of establishing magazines and theatres, has earned a high reputation in the literary history of Kassa. However, it lasted only five years and terminated when Kazinczy - soon after the death of Joseph II. - lost his job as inspector of education in 1791. Hungarian literary life in Kassa began to decline as a consequence, and was only sustained by the short-lived periodicals Magyar Museum and Orpheus. The Theatre of Kassa was, however, famous country-wide, and many celebrated actresses started their career there including Déryné and Róza Laborfalvy. The theatre was maintained by the surrounding county rather than by the city of Kassa itself and hosted mostly German-language performances.

By the 1890's most of the German inhabitants had voluntarily assimilated to the Hungarian population, adopting the Hungarian language, and as a consequence their demand for Hungarian newspapers and Hungarian-language theatre increased. These newspapers, previously published weekly or even less often, began to be issued more frequently, and local writers also started to appear in them. 
In 1893 the Literary Society of Kassa and a couple of months later an institution called the Home for Journalists were established. However, Kassa was too small for two similar societies and both clubs rapidly experienced a decline in their membership. Already in 1896 a merger had been suggested, and on February 17, 1898 the first joint meeting was convened. The merged society was named the Kazinczy Circle and rented two rooms in Hollander House on the Main Street. ${ }^{94}$ Mór Katona, professor of law, became president, while Bishop Zsigmond Bubics and Zsigmond Péchy, lord-lieutenant of the county, became honorary presidents. One of Ferenc Kazinczy's grandchildren, the wife of notary dr. Gyula Offenheimer of Kassa, was also invited to the first assembly.

The first publication of the new society was issued in March 1898: a memorial album for the fiftieth anniversary of the 1848 revolution. The organisation's activities were regular and intensive, with major festivities arranged every two weeks. Concerts and public readings were even held in the City Hall. Memorial tablets were erected and famous guests, most of them writers and poets, were invited to these events. In its daily activity, the membership 'strove unceasingly to raise national culture'. ${ }^{95}$ From the beginning, the association had a social, a literary, a journalism and a legal sections, as well as a library which was opened to the public on December 26, $1902 .{ }^{96}$ The rented rooms and the library hosted events with large audiences. The number of events organized by the circle increased to $20-25$ per season during the first decade of the $20^{\text {th }}$ century. ${ }^{97}$

\section{The membership of the association}

Between 1898 and 1901 the number of permanent members was 197, whose social distribution is shown in the following table.

Table 1.

Social composition of the membership of the Kazinczy Circle between 1898-1904.

Number of members from different social backgrounds and their percentage in parentheses

\begin{tabular}{cccccccc}
\hline & Officials & Teachers & $\begin{array}{c}\text { Market based } \\
\text { intellectuals }\end{array}$ & Bourgeoisie & $\begin{array}{c}\text { Land } \\
\text { owners }\end{array}$ & Students & Total \\
\hline $\mathbf{1 8 9 8 - 1 9 0 1}$ & $73(37)$ & $38(19.3)$ & $44(22.4)$ & $31(15.8)$ & $10(5)$ & $1(0,5)$ & $197(100)$ \\
$\mathbf{1 9 0 1 - 1 9 0 4}$ & $79(39.3)$ & $35(17.4)$ & $32(15.9)$ & $36(17.9)$ & $11(5,5)$ & $8(4)$ & $201(100)$ \\
\hline
\end{tabular}

Source: Géza Gerlóczy, ed., A Kassai Kazinczy-Kör évkönyve 1898-1901 (Kassa: Vitéz A. könyv-, kő- és münyomdája, 1901).; Béla Blanár, ed., A Kassai Kazinczy-Kör évkönyve 1901-1904 (Kassa: Kazinczy-kör, 1904).

The 73 members marked in the first column of the table above included all state and county officials, as well as those employees of the city council who had 
at least as much income as a secondary school teacher. Market based intellectuals included non-state officials or intellectuals with higher education: private doctors, pharmacists, lawyers. The bourgeoisie includes middle managers of private companies, like officials in banks or insurance companies, and entrepreneurs owning middle-sized companies, retailers and craftsmen. The typology above and in the following was based on the social historiography paradigm emphasizing the contrast between state employed middle class and capitalist or manufacturer bourgeoisie. If we wish to gain an idea of the wider social context, we can compare the circle's social distribution against the ratios of the different occupational groups in Kassa's population.

Table 2 .

The distribution of Kassa's population by economic sectors in 1890 and 1900

\begin{tabular}{ccccccccc}
\hline & Agriculture & Industry & Commerce & Transport & $\begin{array}{c}\text { Public } \\
\text { service }\end{array}$ & Military & Other $^{98}$ & All \\
\hline $\mathbf{1 8 9 0}$ & 1012 & 11263 & 2540 & 1914 & 2752 & 3792 & 8892 & 32165 \\
$\mathbf{1 9 0 0}$ & 832 & 14644 & 3606 & 2717 & 3693 & 5294 & 9316 & 40102 \\
\hline
\end{tabular}

Source: A Magyar Szent Korona országainak 1900. évi népszámlálása. 2. rész A népesség foglalkozása községenként (Budapest: Magyar Kir. Központi Statisztikai Hivatal, 1904). 32-4.

Within the industrial workforce, officials made up only $1.8 \%$, artisans and retailers $38 \%$, and the rate of non-manual workers in medium-sized plants was $3.6 \%$. The rate of the bourgeoisie in Kassa was about $5.4 \%$, while the 772 public and non-public officials in 1890 and the 1041 clerks in 1900 accounted for $2.4 \%$ and $2.6 \%$ of the population respectively. ${ }^{99}$ Therefore, teachers were the most overrepresented group in the membership of the Kazinczy Circle, since their rate in the town's population was less than one percent. The high rate of officials reflects the function of Kassa as an administrative centre. Among retailers and artisans of middle-sized companies and of medium incomes, many families came from the old patrician strata of the town. Land owners were a mixed group including not only Hungarian noble dynasties, but German merchant families, too. Distribution didn't change a lot until the turn of the century.

We can conclude that in the membership of the Kazinczy Circle every middle stratum was involved, and their rates largely represented the social distribution of the local population. The state employed middle class and the private bourgeoisie were the most prominent members of this dynamic network. Despite the high numbers of local families, it is worth noting that membership in this society was a more important factor in city life than having been born in Kassa. For example, Ferenc Sziklay was born outside of the city (in a small mining village, Aranyida (today Zlatá Idka), $23 \mathrm{~km}$ from Kassa), nor was his family native to Kassa - still 
he was accepted without any reservations. The Brósz family came from northern Saxon towns, and were still the most wealthy and respected citizens in late $19^{\text {th }}$ century Kassa. ${ }^{100}$

A significant part of the middle class in Kassa had noble or gentry ancestry, while the bourgeoisie included mostly German trading families. ${ }^{101}$ Of the seventeen merchant members eleven were German, five were Jewish and only one was Hungarian. ${ }^{102}$ The fourteen private office and banking staff included eight of German, two of Jewish and four of Hungarian origin. Among non-state employed intellectuals the rate of Hungarians and Jews was higher, while almost half of the teachers were Germans. Among middle class occupations the rate of Hungarians was one and half times higher than that of Germans. Of those who were registered merely as land owners each had aristocratic ancestry, whether German or Hungarian - like the baronesses Georgina and Malvina Melczer. Moreover, Sándor Esterházy was registered as a professor of law, Lajos Kemény as an archivist and Zsigmond Péchy as lord-lieutenant, although all of them were members of old aristocratic families and owners of extensive lands. Omitting their titles from the yearbooks also suggests the progressive and inclusive attitude of the society.

The overrepresentation of teachers in the membership of the Kazincy Circle denotes the increased importance of this profession in social and public life as a result of the expansion of education and literacy in nineteenth century Hungary. Moreover, teachers having a high prestige in the society despite their relatively low incomes is a clear sign that income was not a single determining factor of position, especially in Kassa, one of the educational centres of the country. Education represented an ethos that was valued by the whole society, thus teachers were entitled to have a say in public affairs. The over-representation of the capitalist and manufacturer bourgeoisie in the Kazinczy Circle also demonstrates how the merchant-patrician strata retained its influence in this period. Most of the bourgeoisie had German origins, but Jews were also overrepresented compared to their ratio in the local population. It should be noted that only 12 out of the 197 members were women. Their social statuses were not determined by their husbands, since most of them were unmarried, including nine schoolmistresses and Mariska Bartóky, the postmistress. The fact itself that these unmarried women were members in such a premier association underscores the importance of occupation rather than factors such as gender in determining the membership of the social elite in Kassa. ${ }^{103}$

Since the ethnic composition of the membership was colourful, the exclusive use of the Hungarian language affected particular members differently. The acculturation of the German minority during the late $19^{\text {th }}$ century was accompanied by Hungarian replacing German in everyday life. Despite the fact that the German minority sympathised with the revolution of 1848 , they continued to use their mother tongue, but two generations later their grandchildren had to learn German 
at school. The case of Slovaks was completely different: they could never became an integrated part of the civic society by using the Slovak language, they had to turn to German or Hungarian in offices, schools or any other domain of institutionalised social life. They could not benefit from the same sense of sympathy during revolutionary times, since minorities and their languages were excluded from the goals of the revolution. In fact the opposite happened, and the use of German language was guaranteed and enforced by the Habsburg restoration after the fall of the revolution. This gives us a different view on the ethnic composition described above.

Table 3.

Distribution of members in the Kaziczy Circle by origin and social strata between 1898-1901

\begin{tabular}{lrrrrrr}
\hline & German & Jewish & Hungarian & Slovak & French & Total \\
\hline Officials & 24 & 4 & 36 & 8 & 1 & 73 \\
Teachers & 15 & 1 & 20 & 2 & - & 38 \\
Bourgeoisie & 15 & 10 & 15 & 3 & 1 & 44 \\
Market based intellectuals & 19 & 7 & 5 & - & - & 31 \\
Land owners & 7 & - & 3 & - & - & 10 \\
Students & 1 & - & - & - & - & 1 \\
All & 81 & 22 & 79 & 13 & 2 & 197 \\
\hline
\end{tabular}

Sources: Géza Gerlóczy, ed., A Kassai Kazinczy-Kör évkönyve 1898-1901 (Kassa: Vitéz A. könyv-, kő- és műnyomdája, 1901).; Századunk névváltoztatásai 1800-1893.

Helyhatósági és miniszteri engedéllyel megváltoztatott nevek gyüjteménye (Budapest: Hornyánszky Viktor, 1895).

In the archive of László Sziklay, elder son of Ferenc Sziklay, the deed of foundation of the Literary Society, the predecessor of the Kazinczy Circle established in 1893, its statutes and calls for support, issued during the first year after its creation, are preserved among other documentation. According to the statutes the 35 members of the elected council were to meet every month and a general assembly, which included at least one-fifth of the members, had its meeting in the first quarter of every year. Fifty-four persons supported the founding of this society, five of whom represented various newspapers in Kassa and its environs, including Abauj-Kassai Bulletin (Abauj-Kassai Közlöny), Kassa Review (Kassai Szemle), a Kaschauer Zeitung, as well as periodicals such as Pannonia and the Felvidéki Bulletin (Pannónia, Felvidéki Közlöny). The membership of the council was basically identical to that of its successor, the Kazinczy Circle - in fact the two consecutive societies were established and maintained mostly by the same persons. Both associations held weekly programs, which were described in more detail in the yearbooks they published. Members gave lectures in line with 
their vocation on these occasions: Ede Szerencsi, a cellist, performed a recital, Géza Szepessi, an engineer, gave a lecture on electricity and Sándor Esterházy, a law professor, lectured on 'Law and the principle of asset allocation', to mention but a few examples. These colourful evenings always attracted a large audience, and permeated Kassa with a buoyant social life. A community was forged, while members worked hard to put their society on a firm basis as they initially had to arrange events on varying sites. Besides the founders, all additional members supported the survival of the society; the library, for example, was established based on donations in the form of both money and books.

The founding members of these societies had been brought together by bonds of kinship and friendship that expanded further during their time as members. For example, László Brósz, a lawyer and founding member became the father-inlaw of Ferenc Sziklay, a later president of the association; another member was Sándor Rohringer, a civil engineer and professor, whose niece married Sziklay's elder son László decades later. Lajos Rosenauer was also a founding member, a civil engineer and a son of a German merchant family, originally from Besztercebánya (today Banská Bystrica). His daughter Márta was married to Sándor Rohringer's younger brother Géza, an undertaker. The association therefore served as a community within the community.

The range of goals that such a circle was at pains to achieve was not exceptional: belles-lettres, arts and science; writing, playing music and involving broader audiences in cultural life. Disseminating the arts among less educated and less wealthy strata through tenders and brochures was part of their mission. Everyday life was characterized by constructive, diligent work, a sense of civic virtue than frivolity or eccentricity. The company's suite of rooms in the centre of town was always open to the public, they were not only an elite club, since the location of the library had been expanding over time. Indeed, community building had been among the goals of the Literary Society and its successor, the Kazinczy Circle right from the outset. The middle strata of the local society - or as it was termed at the time, the 'erudite section' - were forged together. Merchants, teachers, judges, mistresses and pharmacists joined forces in support of a community which was otherwise fairly virtual.

\section{Conclusions}

It is obvious that such a state of affairs as described above could not have developed in a short time: the situation where the state-employed middle classes and the business bourgeoisie equally appreciated each other was a consequence of a complicated, sensitive and, therefore, vulnerable social superstructure, which needed time to take shape. Under different circumstances, as in Budapest or Debrecen, ${ }^{104}$ the gentry middle classes disdained the recently assimilated bourgeoisie, while 
in many of the towns of northern Hungary the largely German-speaking bourgeoisie was quite exclusive. ${ }^{105}$ Living in a small city with a 'neighbourhood' air like Kassa in the $19^{\text {th }}$ century, a bureaucratic and educational centre with a large bourgeoisie mostly of German origin, both groups learned to tolerate and cooperate with each other. They lived side by side in the same central district, just as the burghers of the town had done before 1848, running the city's affairs jointly.

Ethnic, occupational and even denominational diversity would not in themselves have been a sufficient basis for the development of so tolerant a society. This was definitely necessary for Kassa to be able to preserve its success in every historical circumstance and to adapt to every situation. The traditional social order prevailed here more than in Pest, and the need to belong to the community was stronger, probably due to slower urbanization. This did not mean a simple survival of feudal norms. It was a societal transformation, a so-called embourgeoisement within a preserved feudal framework, and this process had already begun decades earlier. ${ }^{106}$

This archaic formation together with the slow increase in population size explains why migrants moving to Kassa could easily acculturate - without having to become assimilated. It was common in numerous towns of northern Hungary in the first half of the $19^{\text {th }}$ century for different organizations, masonic lodges, city councils or social associations to be composed of a whole range of changing social strata. This was demonstrated by the openness of Kassa's middle strata: an intellectually devoted society composed of people with diverse ancestry, prestige and occupation, yet forming a tight personal network.

Accommodating some groups (notably the Jewish bourgeoisie), but at the same time excluding the Slovak minority triggered a response on a wider economic and political scale. After WWI this protracted social conflict contributed to the interruption of economic relations between Hungary and Czechoslovakia. ${ }^{107}$ At the same time, Slovaks were mostly excluded from the development of the middle strata during the nineteenth and early twentieth centuries, as a consequence of the almost exclusive use of the Hungarian language. The entire process was embedded in a much wider social complex - as Elena Mannová concluded: the predominance of an agrarian society of Slovakia, the predominance of small towns, the dominance of the petty bourgeoisie, a multilayered ethnic structure, confessional differences, regional differentiation and unstable political development. ${ }^{108}$

\section{References}

Áfra János, 1969. Móricz Zsigmond irodalmi estje Kassán 1914-ben. Irodalomtörténet 51 (1), $166-81$.

Archer, Melanie, Blau, Judith R., 1993. Class Formation in Nineteenth-Century America: The Case of the Middle Class. Annual Review of Sociology 19, 17-41. 
Bácskai Vera, 1988. Városok és városi társadalom Magyarországon a XIX. század elején. Budapest, Akadémiai Kiadó,

Bácskai Vera, 2006. A régi polgárságról. In Kövér, Gy., ed., Zsombékok. Középosztály és iskoláztatás Magyarországon. Budapest: Századvég Kiadó.

Beluszky Pál, 1998. A Felvidék városhálózata a 20. század elején In Frisnyák Sándor ed. A Felvidék történeti földrajza. Nyíregyháza: MTA, 439-454.

Beluszky Pál, 2001. A modernizáció területi különbségei. Rubicon 12 (8-9), 27-33.

Berend, Ivan, 2012. An Economic History of Nineteenth-Century Europe: Diversity and Industrialization. Cambridge: Cambridge University Press.

Beudant, François-Sulpice, 1822. Voyage minéralogique et géologique en Hongrie pendant l'année 1818 II. Paris: Chez Verdière, 193-4.

Blanár Béla ed. 1904. A Kassai Kazinczy-Kör évkönyve 1901-1904. Kassa: Kazinczy-kör, 25-9.

Bluestone, Daniel M., 1991. "The pushcart evil”. Peddlers, merchants, and New York City's streets, 1890-1940. Journal of Urban History 18 (1), 68-92.

Bourdieu, Pierre, 1977. Outline of a Theory of Practice. Cambridge: Cambridge University Press, 281-4.

Bourdieu, Pierre, 1985. The Social Space and the Genesis of Groups. Theory and Society 14 (6), 723-44.

Bumová, Ivica, 2003. Vymedzenie strednej vrstvy v roku 1930. Sociálna a profesijná diferenciácia obyvatel'stva na príklade mesta Dolný Kubín. Etnologické rozpravy 10 (2), 94-122.

Čičaj, Viliam, 2005. Šl'achta - staronový problém slovenskej historiografie. Česko- slovenská historická ročenka, 11-18.

Correspondence of Ferenc Sziklay, Fond 158. OSZK Kt.

Czoch Gábor, 1998. Kassa polgársága a 19. század első felében. Limes 11 (2-3), 55-87.

Csíki Tamás, 1999. Városi zsidóság Északkelet- és Kelet-Magyarországon. Budapest: Osiris.

Demmel, József, 2012. Stav zemiansky národa slovenského - Uhorská šlachta slovenského pôvodu. Forum Historiae 6 (2), 56-67.

Dixhoorn, Arjan van, Speakman Sutch, Susie 2008. Introduction. In A. van Dixhoorn and S. Speakman Sutch, eds. The reach of the republic of letters : literary and learned societies in late medieval and early modern Europe. Leiden-Boston: Brill.

Doughan, David, Gordon, Peter, 2006. Women, Clubs and Associations in Britain. London: Routledge.

Dudeková,Gabriela, 2008. Spoločnost', kultúrny a spoločenský život. In Jakeová, Elena, Dudeková, Gabriela, Mannová, Elena, Kováč, Dušan, eds. Slovensko v 20. storoči. 2nd. Volume 'Prvá svetová vojna 1914-1918'. Bratislava: Veda, Vydavatel'stvo SAV, 161-214.

Editorial, 1898. Felsőmagyarország, January 13,; Kassai Hírlap, January 14, 1898.

Erdei Ferenc, 1976. A magyar társadalom a két háború között. Valóság 19 (4), 23-53, 19 (5), 36-58.

Gerlóczy Géza, ed. 1901. A Kassai Kazinczy-Kör évkönyve 1898-1901. Kassa: Vitéz A. könyv-, kő- és münyomdája,

Goldthorpe, John H., 1960. Social Stratification in Industrial Society. The Sociological Review 8, 97-122.

Gömöry János, 1964. Emlékeim egy letünt világról. Budapest: Szépirodalmi Könyvkiadó.

Gyáni Gábor, 1997. A középosztály társadalomtörténete a Horthy-korban. Századok 131 (6), 12651304.

Gyáni Gábor, 1995. Elkülönülés és egységesülés. Szegregáció és egyesületek a dualizmus kori Vásárhelyen. In Mikó Zs., ed. Rendi társadalom - Polgári társadalom 4. Mezöváros - kisváros, Debrecen: Csokonai Kiadó.

Hajdú Tibor, 1996. Nemesi tisztikarból polgári tisztikar. Történelmi Szemle, 38 (4), 343-351. 
Hanák Péter, 1997. Társadalmi struktúrák a 19. századi Közép-Európában. Történelmi Szemle 39(2), 159-79.

Haupt, Heinz-Gerhard, Kocka, Jürgen, 2009. Comparative and transnational history : Central European approaches and new perspectives. New York-Oxford: Berghahn Books.

Henschel, Frank, 2014. Religions and the Nation in Kassa before World War I. Hungarian Historical Review 3 (4), 850-874.

Holec, Roman, 1998. Kultúra bývania meštianstva na Slovensku pred prvou svetovou vojnou. In Mannová, Elena, ed. Meštianstvo a občianska spoločnost’ na Slovensku 1900-1989. Bratislava: AEP, $175-188$.

Innes, Joanna, 1992. Politics, Property and the Middle Class. Parliamentary History 11(2), 286-92.

Kalmár Elek, ed. 1907. Középiskolai tanári névkönyv. X. névkönyv 1906-07. Löcse.

Kalmár Elek, ed. 1910. Középiskolai tanári névkönyv. XI. névkönyv 1909-10. Lőcse.

Kardos Gyula, 1919. A Kassai Kazinczy-kör 1914-1917. évi jelentése. Kassa: Szent Erzsébet Nyomda.

Kassa sz. k. v. és Abaújtorna V. M. Czím És Lakásjegyzéke. 1906. Kassa: Koczányi Béla,

Kassai Kazinczy-kör. 1911. Editorial. Kultura 1, 13.

A Kassai Kazinczy-kör levele Mikszáth Kálmánnak. 1909. Kassa Május 27. In Méreiné Juhász M., ed. Mikszáth Kálmán levelezése. III. Budapest: Akadémiai Kiadó, 1961.

Kassai országos dalünnep. 1901. Vasárnapi Újság 48, 34.

Katus László, 1989. Nemzetek és népszaporulat. In Glatz Ferenc, ed. Magyarok a Kárpát-medencében. Budapest, Pallas, 171-174.

A Kazinczy-Társaság ujjáébredéséhez. 1920. Kassai Hirlap, 1920. szeptember 28.

Kendall, Diana, 2008. Members Only: Elite Clubs and the Process of Exclusion. Lanham: Rowman and Littlefield Publishers

Kocka, Jürgen, 1980. White Collar Workers in America. 1890-1940. Beverly Hills: Sage.

Koudela Pál, 2007. A kassai polgárság 1918 elött és után. Budapest, PhD dissertation.

Koudela Pál, 2015. A Piece of Late Modern Age History of Hungary through the Rombauer Family Tree. 1. Prague Papers on the History of International Relations 19 (1), 28-45.

Koudela Pál, 2016. Négy felvidéki város. Budapest: L’Harmattan.

Kovács, Éva, 1991. A kassai zsidóság etnikai identitása a két világháború között (1918-1938). PhD dissertation, ELTE.

Kovalcsik József, 1987. A kultúra csarnokai. II. Budapest: Művelődéskutató Intézet.

Kováts Dániel, 2009. „Fény s nagyvilág énnékem Széphalom”. A Kazinczy Ferenc emlékhely története és hatása. Sátoraljaújhely: Kazinczy Ferenc Társaság.

Kövér György, Gyáni Gábor, 2003. Magyarország társadalomtörténete a reformkortól a második világháborúig. Budapest: Osiris Kiadó.

Kövér György, 1997. Egy biedermeier cipszer polgárcsalád életstratégiája. In Németh Zs., Sasfi Cs., eds. Rendi társadalom - polgári társadalom 7. Budapest: Csokonai Kiadó, 175-9.

Langford, Paul, 2002. Englishness Identified'Manners and Character 1650-1850. Oxford: Oxford University Press.

Langford, Paul, 1991. Public Life and the Propertied Englishman 1689-1798. Oxford: Oxford University Press.

Lekly Gyula, 1896. Kassa társadalma’, in Magyarország vármegyéi és városai. Abaúj-Torna vármegye és Kassa, ed. S. Borovszky and J. Sziklay, Budapest: Apolló, 209-11.

Lipták, Lubomír, 1992. Politické strany na Slovensku 1860-1989. Bratislava: Archa, 16-18.

Lipták, Lubomir, 1998. Zmeny elít v meštianskej spoločnosti v prvej tretine 20. storočia. In Meštianstvo a občianska spoločnost’ na Slovensku 1900-1989. Mannová, Elena, ed. Bratislava: AEP, 59-70. 
A Magyar Szent Korona országainak 1900. évi népszámlálása. 8. rész. Közszolgálati ágak és szabadfoglalkozások. Budapest: Magyar Kir. Központi Statisztikai Hivatal, 1906.

Magyarország tiszti cím- és névtára - 17. évfolyam. 1898. Budapest: A M. Kir. Központi Statisztikai Hivatal.

Mannová, Elena, 1990. Spolky a ich miesto v živote spoločnosti na Slovensku v 19. a 20. storočí. Stav a problémy výskumu. Historický časopis 38 (1), 15-27.

Mannová, Elena, 1991. Prehl'ad vývoja spolkového hnutia na Slovensku z aspektu formovania občianskej spoločnosti. In Občianska spoločnost'. Problémy a perspektívy v ČSFR. Stena, Ján, ed. Bratislava: Sociologický ústav SAV, 71-79.

Mannová, Elena, 1997. Meštianstvo na Slovensku v 19. a 20. storočí ako predmet historického výskumu. Historický časopis 45 (1), 85-90.

Mannová, Elena, 1998. Podmienky vývoja meštianskych vrstiev na Slovensku v 20. storočí. In Meštianstvo a občianska spoločnost’ na Slovensku 1900-1989. Mannová, Elena, ed. Bratislava: AEP, 9-16.

Mannová, Elena, 1999. Dobročinné spolky a konštruovanie kolektívnych identít. In Csáky, Moritz, Mannová, Elena, eds Kolektívne identity v strednej Európe v obdobi moderny. Bratislava: AEP, 195-212.

Mannová, Elena, 2006. Verejnost’ verzus rodinný krb? Ženy v spolkoch na Slovensku v 19. storočí. Človek a spoločnost' 9 (4), 37-48.

Mannová, Elena, ed. 1998. Meštianstvo a občianska spoločnost' na Slovensku 1900-1989. Bratislava: AEP.

Mezei István, 2008. Városok Szlovákiában és a magyar határ mentén. Somorja-Pécs, Fórum Kisebbségkutató Intézet-MTA RKK,

Mócsy, István, 1983. The Effects of World War I The Uprooted: Hungarian Refugees and Their Impact on Hungary's Domestic Politics, 1918-1921. New York, Columbia University Press.

Morris, Robert J. 2005. Men, Women and Property in England, 1780-1870: A Social and Economic History of Family Strategies amongst the Leeds Middle Class Cambridge: Cambridge University Press.

Morton, Clay, 2006. South of 'Typographic America': Orality, Literacy, and Nineteenth-Century Rhetorical Education. South Atlantic Review 71(4), 45-61.

Motschmann, Uta, ed. 2015. Handbuch der Berliner Vereine und Gesellschaften 1786-1815. Berlin, Boston: De Gruyter.

Mráz, Andrej, 1961. 'Vznik Matice slovenskej a jej význam v období zvýšeného národného útlaku.' Matica slovenská.. 35-49.

Nicolay, Helen, 1935. Sixty Years of the Literary Society. Washington, D.C.: Literary Society of Washington.

Olivova, Věra, 1972. The Doomed Democracy, Czechoslovakia in a Disrupted Europe 1914-1938. London: Sidgwick and Jackson.

Orosz László, 1999. A cenzor figyelme. A Bánk Bán értelmezéseinek a története. Budapest: Krónika Nova.

Paget, John, 1839, Hungary and Transylvania; with remarks on their condition, Social, Political, and Economical. I. London: John Murray.

Pajkossy Gábor, 1993. Egyesületek a reformkori Magyarországon. História 15 (2) 6-9.

Pálesch Ervin, ed. 1919. Csehszlovák Törvények és rendeletek gyüjteménye. Prešov: Molnár, 589600.

Pálmány Béla, 1997. A magyarországi nemesség társadalmi tagolódása (1686-1815). In Ódor I., Pálmány B., Takács P. eds, Rendi társadalom, polgári társadalom 9. Mágnások, birtokosok, cimerlevelesek, Debrecen: KLTE. 
Pálmány Béla, 1998. A felföldi mezővárosok típusai az úrbérrendezéstől a közbérrendezésig (1767-1871). Limes 11( 2-3), 21-55.

Pašiak, Ján, 1998. Meštianstvo a občianska spoločnost' na Slovensku v kontexte sídelného vývoja 1900-1989. In Mannová. Elena, ed. Meštianstvo a občianska spoločnost’ na Slovensku 19001989. Bratislava: AEP, 17-32.

Pintér Jenő, 1941. Magyar irodalom a XX. század első harmadában. 1. Pintér Jenő magyar irodalomtörténete. VIII. kötet. Budapest, Stephaneum Ny.

Pollák, Robert, 1985. Sprievodca po expozícii Košice v stredoveku. Bratislava: ERPO, 10-36.

Popelková, Katarína, 1999. Mestskí vinohradníci ako sociálna skupina. In Salner, Peter, Beňušková, Zuzana, eds. Diferenciácia mestského spoločenstva v každodennom živote. Bratislava: Zing Print, 115-130.

Pór Edit, ed. 1988. A magyarországi egyesületek címtára a reformkortól 1945-ig, I-III. Budapest: Müvelődéskutató Intézet.

Sáposová, Zlatica, 2013. Voluntary Associations in Košice, Slovakia - An Introduction to the Subject of Associations and Their Activities. Studia Historyczne 56 (4), 527-537.

A Sárosvármegyei Múzeum megnyitása. 1907. Múzeumi és könyvtári értesitö 1, 2.

Schalkház Lipót, 1944. Dalos Kassa. A Kassai Zenekedvelök Koszorús Dalegyletének története. Kassa: Grafika.

Szarka László, 1993. Magyarosodás és magyarosítás a felső magyarországi szlovák régióban a kiegyezés korában. Somogyi Éva, ed. Polgárosodás Közép-Európában. Budapest: MTA TTI, $35-47$.

Századunk névváltoztatásai 1800-1893. Helyhatósági és miniszteri engedélylyel megváltoztatott nevek gyüjteménye. 1895. Budapest, Hornyánszky Viktor kiadása,

Szekfü Gyula, 1938. Három nemzedék, és ami utána következik. Budapest: Királyi Magyar Egyetemi Nyomda.

Sziklay János, Borovszky Samu, 1896. Abauj-Torna vármegye és Kassa. Magyarország vármegyéi és városai. Budapest: „Apollo” Irodalmi és Nyomdai Részvénytársaság.

Sziklay László, 1957. Brósz Jonathán. A Szegedi Pedagógiai Föiskola Évkönyve, Szeged, SZPF, 131-153.

Szvatkó Pál, 1938. Szlovenszkói városok. In Tamás M., ed. Tátra-almanach. Szlovenszkói városképek. Bratislava: Tatra.

Tímár, Lajos, 1993. Vidéki városlakók. Debrecen társadalma, 1920-1944. Budapest: Magvető.

Tkadlečková-Vantuchová, Jarmila, 1969. Živena - spolok slovenských žien. Bratislava: Epocha.

Tóth Orsolya, 2009. A mulandó és a múlhatatlan. Kazinczy és kortársai irodalmi szemléletmódjainak diszkurziv határairól. Budapest: Ráció Kiadó.

Vörös Károly, 1975. A modern értelmiség kezdetei Magyarországon. Valóság 18 (10), 1-20.

Vörös, Károly, 1980. A magyarországi társadalom (1790-1848). In Mérei Gyula, Vörös Károly eds. Magyarország története 5. 1790-1848. 1. Budapest, Akadémiai Kiadó, 547-601.

Weber, Max, 1922. Grundriß der Sozialökonomik III. Abteilung Wirtschaft und Gesellschaft. Tübingen: Paul Siebeck.

Weis István, 1942. Hazánk társadalomrajza. Budapest: Országos Közoktatási Tanács.

Wohl, Janka, 1882. Egy nagyvilági hölgy: Az otthon. Útmutató a ház célszerü és izlésteljes berendezésére s vezetésére. Budapest.

Wülfing, Wulf, Bruns, Karin, Parr, Rolf, 1998. Handbuch literarisch-kultureller Vereine, Gruppen und Bünde 1825-1933. Stuttgart-Weimar: Metzler, 98-9.

Zozaya, María, 2007. Del ocio al negocio. Redes y capital social en el Casino de Madrid, 18361900. Madrid: La Catarata. 


\section{Notes}

1 Fine examples of this include: Orsolya Tóth, A mulandó és a múlhatatlan. Kazinczy és kortársai irodalmi szemléletmódjainak diszkurzív határairól. (Budapest: Ráció Kiadó, 2009); Elena Mannová, 'Spolky a ich miesto v ţivote spoločnosti na Slovensku v 19. storočí. Stav a problémy výskumu.' Historický časopis 38, no. 1 (1990): 15-27.; Clay Morton, 'South of ,Typographic America': Orality, Literacy, and Nineteenth-Century Rhetorical Education.' South Atlantic Review 71, no. 4 (2006): 45-61.; Uta Motschmann, (ed.). Handbuch der Berliner Vereine und Gesellschaften 1786-1815. (Berlin, Boston: De Gruyter, 2015)

2 Decision making and its legitimacy were mostly formalized in $19^{\text {th }}$ century Hungary. Along with the strengthening of civic society, a more 'bottom-up' political structure developed.

3 We use the term 'bourgeoisie' to refer to the business and industrial elite. (German historians distinguish the wealthy elite or Besitzbürger as against the intellectuals or Bildungsbürgertum, while in the French terminology bourgeois is juxtaposed to the public role of the citizen, called citoyen). In traditional Hungarian historical writing the concept of the middle class refers to the gentry and the officials. This way the distinction between bourgeoisie and middle class refers to the antagonism between capitalists and the role of state offices, filled mostly by noblemen in periods prior to the late $19^{\text {th }}$ century.

4 This idea was already present in the first half of the $20^{\text {th }}$ century in the works of Gyula Szekfü and István Weis, and survived in later historiography through such prominent Hungarian historians as Péter Hanák.

5 Elena Mannová wrote about this phenomenon many times, and, for a broader perspective: Viliam Čičaj, 'Šl'achta - staronový problém slovenskej historiografie.' Česko - slovenská historická ročenka, (2005): 11-18. is a good examle.

6 A detailed example can be found in Kovács Éva's dissertation: 'A kassai zsidóság etnikai identitása a két világháború között (1918-1938)' (PhD dissertation, ELTE, 1991)

7 Gábor Czoch, 'Kassa polgársága a 19. század első felében' Limes 11, no. 2-3 (1998): 55.

8 László Orosz, A cenzor figyelme. A Bánk Bán értelmezéseinek a története. (Budapest: Krónika Nova, 1999), 18.

9 This was noticed by historians of different periods, like Granasztói György, Czoch Gábor and Kovács Éva.

10 Frank Henschel, 'Religions and the Nation in Kassa before World War I' Hungarian Historical Review 3, no. 4 (2014): 850-874.

11 Arjan van Dixhoorn and Susie Speakman Sutch, 'Introduction' in The reach of the republic of letters : literary and learned societies in late medieval and early modern Europe eds. A. van Dixhoorn and S. Speakman Sutch (Leiden-Boston: Brill, 2008). 1.

12 József Kovalcsik, A kultúra csarnokai. Vol. II. (Budapest: Müvelődéskutató Intézet, 1987), 71-119.

13 Gyula Lekly, 'Kassa társadalma', in Magyarország vármegyéi és városai. Abaúj-Torna vármegye és Kassa, ed. S. Borovszky and J. Sziklay (Budapest: Apolló, 1896), 209-11.

14 Andrej Mráz, 'Vznik Matice slovenskej a jej význam v období zvýšeného národného útlaku.' Matica slovenská (1961): 35-49.; Jarmila Tkadlečková-Vantuchová, Živena - spolok slovenských žien. (Bratislava: Epocha, 1969), 207.

15 Elena Mannová, 'Prehl'ad vývoja spolkového hnutia na Slovensku z aspektu formovania občianskej spoločnosti.' in: Občianska spoločnost'. Problémy a perspektívy v ČSFR. ed. Ján Stena (Bratislava: Sociologický ústav SAV, 1991), 71-79.

16 Szarka László, 'Magyarosodás és magyarosítás a felső magyarországi szlovák régióban a kiegyezés korában.' Somogyi Éva (ed.) Polgárosodás Közép-Európában. (Budapest: MTA TTI, 
1993): 35-47.; Beluszky Pál, 'A Felvidék városhálózata a 20. század elején.' Frisnyák Sándor (ed.) A Felvidék történeti földrajza. (Nyíregyháza: MTA, 1998): 439-454.

17 'Kassai országos dalünnep.' Vasárnapi Újság 48, no. 34. (1901): 551.

18 'A Kassai Kazinczy-kör levele Mikszáth Kálmánnak. Kassa 1909. Május 27.' in Mikszáth Kálmán levelezése. III., ed. M.Méreiné Juhász (Budapest: Akadémiai Kiadó, 1961). 355.; János Áfra, 'Móricz Zsigmond irodalmi estje Kassán 1914-ben', Irodalomtörténet 51, no. 1 (1969): 166-81.

19 'A Sárosvármegyei Múzeum megnyitása.' Múzeumi és könyvtári értesitő 1, no. 2. (1907): 105.

20 Jenő Pintér, Magyar irodalom a XX. század első harmadában. 1. Pintér Jenő magyar irodalomtörténete. VIII. kötet. (Budapest, Stephaneum Ny., 1941)

21 Helen Nicolay, Sixty Years of the Literary Society (Washington, D.C.: Literary Society of Washington, 1935), 6.

22 Wulf Wülfing, K. Bruns and R. Parr, Handbuch literarisch-kultureller Vereine, Gruppen und Bünde 1825-1933 (Stuttgart-Weimar: Metzler, 1998), 98-9.

23 Gábor Pajkossy, 'Egyesületek a reformkori Magyarországon', História 15, no. 2 (1993): 6-9.; L'ubomír Lipták, Politické strany na Slovensku 1860 - 1989. (Bratislava: Archa, 1992), 16-18.

24 Elena Mannová, 'Podmienky vývoja meštianskych vrstiev na Slovensku v 20. storočí.' in Meštianstvo a občianska spoločnost' na Slovensku 1900-1989. ed. Elena Mannová (Bratislava: AEP, 1998), 9-16.

25 István Mócsy, The Effects of World War I The Uprooted: Hungarian Refugees and Their Impact on Hungary's Domestic Politics, 1918-1921. (New York, Columbia University Press, 1983)

26 Gabriela Dudeková, 'Spoločnost', kultúrny a spoločenský život.' in Slovensko v 20. storočí. 2nd. Volume ,Prvá svetová vojna 1914-1918'. eds. Elena Jakeová - Gabriela Dudeková - Elena Mannová - Dušan Kováč (Bratislava: Veda, Vydavatel'stvo SAV, 2008), 161-214.

27 József Demmel, 'Stav zemiansky národa slovenského - Uhorská šlachta slovenského pôvodu' Forum Historiae 6, no. 2. (2012): 56-67.

28 Potemra (1983)

29 Elena Mannová, 'Dobročinné spolky a konštruovanie kolektívnych identít.' in: Kolektívne identity v strednej Európe v obdobi moderny. eds. Moritz Csáky, Elena Mannová (Bratislava: AEP, 1999), 195-212; Elena Mannová, 'Spolky a ich miesto v ţivote spoločnosti na Slovensku v 19. a 20. storočí. Stav a problémy výskumu. 'Historický časopis 38, no.1, (1990): 15-27.

30 Pál Beluszky, 'A Felvidék városhálózata a 20. század elején' in: A Felvidék történeti földrajza, ed. S.Frisnyák (Nyíregyháza: MTA, 1998), 440.

31 Robert Pollák, Sprievodca po expozícii Košice v stredoveku (Bratislava: ERPO, 1985), 10-36.

32 Beluszky, 'A Felvidék városhálózata a 20. század elején', 446.

33 A Jesuit college had been operating in Kassa since 1657, and in 1660 Leopold I endowed it with the same rights as those enjoyed by the universities of Vienna, Prague and Nagyszombat (Trnava). In the case of another example a Magyar Museum was established here in 1788 by Chamber Officer János Batsányi, Dávid Baróti Szabó, a Jesuit teacher and later secular priest and Ferenc Kazinczy.

34 Béla Pálmány, 'A felföldi mezővárosok típusai az úrbérrendezéstől a közbérrendezésig (1767-1871)', Limes 11, no. 2-3 (1998): 21-55.

35 Pál Beluszky, 'A modernizáció területi különbségei', Rubicon 12, Nos. 8-9. (2001): 27-33.

36 The act which allowed Jews to settle down in towns and cities was issued in Kassa in 1840 but in many other places was not passed until the 1860s or 1870s. However, even here, efforts were made to prevent immigration. Whether the reason for this was social exclusion or the economically based fear of the local community is not yet clear, but the difference is nevertheless significant. 
37 Pál Szvatkó, 'Szlovenszkói városok', in Tátra-almanach. Szlovenszkói városképek, ed. M.Tamás (Bratislava: Tatra, 1938), 33.

38 Vera Bácskai, 'A régi polgárságról', in Zsombékok. Középosztály és iskoláztatás Magyarországon, ed. Gy. Kövér (Budapest: Századvég Kiadó, 2006), 29.

39 Éva Kovács, 'A kassai zsidóság etnikai identitása a két világháború között (1918-1938)' (PhD dissertation, ELTE, 1991), Appendix: interviews. This has been published, at least in part. Please check to see if this interview is included in her later work.

40 István Weis, Hazánk társadalomrajza (Budapest: Országos Közoktatási Tanács, 1942), 77.

41 Paul Langford, Public Life and the Propertied Englishman 1689-1798 (Oxford: Oxford University Press, 1991).; Robert J. Morris, Men, Women and Property in England, 1780-1870: A Social and Economic History of Family Strategies amongst the Leeds Middle Class (Cambridge: Cambridge University Press, 2005).

42 Joanna Innes, 'Politics, Property and the Middle Class', Parliamentary History 11, no. 2 (1992): 288.; Paul Langford, Englishness Identified 'Manners and Character 1650-1850 (Oxford: Oxford University Press, 2002), 10.

43 Melanie Archer and Judith R. Blau, 'Class Formation in Nineteenth Century America: The Case of the Middle Class', Annual Review of Sociology 19, (1993): 17-41.

44 Berend notes that traditional handicrafts continued to predominate even in Britain during the mid-19 $9^{\text {th }}$ century. Ivan Berend, An Economic History of Nineteenth-Century Europe: Diversity and Industrialization. (Cambridge University Press, 2012): 181. This goes contrary to the traditional way in which industrialization changed social structures. John H. Goldthorpe, 'Social Stratification in Industrial Society.' The Sociological Review 8 (1960): 97-122.

45 Ferenc Erdei, 'A magyar társadalom a két háború között', Valóság 19, no. 4, no. 5, (1976): 23-53, 36-58.

46 Gyula Szekfü, Három nemzedék, és ami utána következik (Budapest: Királyi Magyar Egyetemi Nyomda, 1938), 383-507.

47 Roman Holec, 'Kultúra bývania meštianstva na Slovensku pred prvou svetovou vojnou.' in Meštianstvo a občianska spoločnost' na Slovensku 1900-1989. ed. Elena Mannová (Bratislava: AEP, 1998), 175-188.; Mannová (1998); Lubomir Lipták, 'Zmeny elít v meštianskej spoločnosti v prvej tretine 20. storočia.' in Meštianstvo a občianska spoločnost' na Slovensku 1900-1989. ed. Elena Mannová (Bratislava: AEP, 1998), 59-70.; Katarína Popelková, 'Mestskí vinohradníci ako sociálna skupina.' in Diferenciácia mestského spoločenstva $v$ každodennom živote. Peter Salner - Zuzana Beňušková (Bratislava: Zing Print, 1999) 115-130.

48 Salner (1998); Popelková (1999); Ivica Bumová, 'Vymedzenie strednej vrstvy v roku 1930 (Sociálna a profesijná diferenciácia obyvatel'stva na príklade mesta Dolný Kubín).' Etnologické rozpravy 10, no. 2. (2003): 94-122.

49 Elena Mannová (ed.), Meštianstvo a občianska spoločnost’ na Slovensku 1900-1989. (Bratislava: AEP, 1998)

50 It was rather a model for a narrow, one-way social mobility in Hungary, emphasizing how obsolete and retrograde the social system was.

51 Péter Hanák, 'Társadalmi struktúrák a 19. századi Közép-Európában’ Történelmi Szemle 39, no. 2, (1997): 159-79. old.

52 Gábor Gyáni, 'A középosztály társadalomtörténete a Horthy-korban', Századok 131, no. 6. (1997): 1265-1304.

53 Archer and Blau, 'Class Formation in Nineteenth-Century America: The Case of the Middle Class' 21.

54 Jürgen Kocka, White Collar Workers in America. 1890-1940 (Beverly Hills: Sage, 1980); Heinz-Gerhard Haupt and Jürgen Kocka, Comparative and transnational history : Central Eu- 
ropean approaches and new perspectives (New York-Oxford: Berghahn Books, 2009) debates the whole question in details.

55 Daniel M. Bluestone, “The pushcart evil" Peddlers, merchants, and New York City's streets, 1890-1940', Journal of Urban History 18, no. 1 (1991): 68-92.

56 Janka Wohl, Egy nagyvilági hölgy: Az otthon. Útmutató a ház célszerü és izlésteljes berendezésére s vezetésére. (Budapest, 1882)

57 Tibor Hajdú, 'Nemesi tisztikarból polgári tisztikar' Történelmi Szemle, 38, no. 4, (1996): 343351.

58 György Kövér and Gábor Gyáni, Magyarország társadalomtörténete a reformkortól a második világháborúig (Budapest: Osiris Kiadó, 2003), 166.

59 Max Weber, Grundriß der Sozialökonomik III. Abteilung Wirtschaft und Gesellschaft (Tübingen: Paul Siebeck. 1922), 228.

60 Bácskai, 'A régi polgárságról', 16.

61 Selmecbánya had the second largest silver ore deposits in the world - behind Argentina - in the $18^{\text {th }}$ century.

62 Both were famous statisticians of the era.

63 Gábor Czoch, 'Kassa polgársága a 19. század első felében' Limes 11, no. 2-3 (1998): 57.

64 John Paget, Hungary and Transylvania; with remarks on their condition, Social, Political, and Economical. Vol. I. (London: John Murray, 1839), 455.; Franpois-Sulpice Beudant, Voyage minéralogique et géologique en Hongrie pendant l'année 1818 II. t. (Paris: Chez Verdière, 1822), 193-4.

65 Vera Bácskai, Városok és városi társadalom Magyarországon a XIX. Század elején (Budapest, Akadémiai Kiadó, 1988) 7-8.

66 Béla Pálmány, 'A magyarországi nemesség társadalmi tagolódása (1686-1815)’ in: Rendi társadalom, polgári társadalom 9. Mágnások, birtokosok, címerlevelesek, ed. Ódor I., Pálmány B. and Takács P. (Debrecen: KLTE, 1997), 57. Count was the second highest rank in the Hungarian aristocracy of the $19^{\text {th }}$ century, with only princes and princesses holding a higher standing. The latter, however, were tied strongly to the court in Vienna and in 1808the title was born by a mere 15 individuals from 14 Hungarian families.

67 Czoch, 'Kassa polgársága a 19. század első felében', 55-87.

68 Ibid., 64-65.

69 Károly Vörös, 'A magyarországi társadalom (1790-1848). Gyula Mérei - Károly Vörös (eds.) Magyarország története 5. 1790-1848. Vol. 1. (Budapest, 1980): 547-601.

70 Ibid., 77.

71 Károly Vörös, ’A modern értelmiség kezdetei Magyarországon' Valóság 18, no. 10 (1975): $1-20$.

72 János Sziklay - Samu Borovszky, Abauj-Torna vármegy és Kassa. Magyarország vármegyéi és városai. (Budapest: “Apollo" Irodalmi és Nyomdai Részvénytársaság, 1896); Edit Pór (ed.), A magyarországi egyesületek címtára a reformkortól 1945-ig, Vol. I-III. (Budapest: Müvelődéskutató Intézet, 1988).

73 Zlatica Sáposová, ' Voluntary Associations in Košice, Slovakia - An Introduction to the Subject of Associations and Their Activities.' Studia Historyczne 56, no. 4. (2013): 527-537. 534.

74 We have to note that the idolization of Ferenc Kazinczy started immediately after his death and become institutionalized at the celebration of the centenary of his birthday in 1859 . The foundation of the Kazinczy Circle was the first formal manifestation of the cult that continues to this day. One example is the journal Széphalom dedicated to him in the period. See: Kováts Dániel, „Fény s nagyvilág énnékem Széphalom”. A Kazinczy Ferenc emlékhely története és hatása. (Sátoraljaújhely: Kazinczy Ferenc Társaság, 2009). 
75 Gyula Kardos, A Kassai Kazinczy-kör 1914-1917. évi jelentése (Kassa: Szent Erzsébet Nyomda, 1919), 77-8.

76 The Crown was the official currency in the Austro-Hungarian Empire between 1892 and 1918.

77 Elek Kalmár (ed.) Középiskolai tanári névkönyv. X. névkönyv 1906-07. (Lőcse, 1907); Elek Kalmár (ed.) Középiskolai tanári névkönyv. XI. névkönyv 1909-10. (Lőcse, 1910)

78 Ervin Pálesch, ed., Csehszlovák Törvények és rendeletek gyüjteménye (Prešov: Molnár, 1919). 589-600.

79 Sándor Márai’s father.

80 Lipót Schalkház, Dalos Kassa. A Kassai Zenekedvelök Koszorús Dalegyletének története (Kassa: Grafika, 1944), 13.

81 János Gömöry, Emlékeim egy letünt világról (Budapest: Szépirodalmi Könyvkiadó, 1964). The situation is aldo applicable to Eperjes, e.g. before 1918 the 'Imre Thököly Freemasons' Lodge' was composed of the following members: four teachers, the city mayor, a chief medical officer, the head of the state architectural office, a Jewish lawyer, a Jewish retailer and a headmaster.

82 Pál Koudela, A kassai polgárság 1918 előtt és után. (Budapest, PhD dissertation, 2007): 222.

83 Ján Pašiak 'Meštianstvo a občianska spoločnost' na Slovensku v kontexte sídelného vývoja 1900-1989.' in Meštianstvo a občianska spoločnost' na Slovensku 1900-1989. ed. Elena Mannová (Bratislava: AEP, 1998), 17-32.

84 Holec (1998).

85 Pierre Bourdieu, 'The Social Space and the Genesis of Groups' Theory and Society 14, no. 6 (1985): 723-44.; Pierre Bourdieu, Outline of a Theory of Practice (Cambridge: Cambridge University Press, 1977), 281-4.

86 Századunk névváltoztatásai 1800-1893. Helyhatósági és miniszteri engedélylyel megváltoztatott nevek gyüjteménye. (Budapest, Hornyánszky Viktor kiadása, 1895)

87 László Katus, 'Nemzetek és népszaporulat.' Ferenc Glatz (ed.) Magyarok a Kárpátmedencében. (Budapest, Pallas, 1989): 171-174.

88 Tamás Csíki, Városi zsidóság Északkelet- és Kelet-Magyarországon. (Budapest: Osiris, 1999)

89 István Mezei, Városok Szlovákiában és a magyar határ mentén. (Somorja-Pécs, Fórum Kisebbségkutató Intézet - MTA RKK, 2008)

90 Pál Koudela, Négy felvidéki város (Budapest: L'Harmattan, 2016). 240. One example of this is the fact that despite their lack of Hungarian, newly arrived Czech officials would rather visit the Hungarian Theatre than Slovak or Czech performances. Along with their appreciation new contacts were formed and plays were translated: a success for both culture and community.

91 David Doughan and Peter Gordon, Women, Clubs and Associations in Britain (London: Routledge, 2006); Diana Kendall, Members Only: Elite Clubs and the Process of Exclusion (Lanham: Rowman and Littlefield Publishers, 2008).; María Zozaya, Del ocio al negocio. Redes y capital social en el Casino de Madrid, 1836-1900 (Madrid: La Catarata, 2007). Examining the composition of club membership is regular in elite studies.

92 Gábor Gyáni, 'Elkülönülés és egységesülés. Szegregáció és egyesületek a dualizmus kori Vásárhelyen', in Rendi társadalom - Polgári társadalom 4. Mezöváros - kisváros, ed. Zs. Mikó (Debrecen: Csokonai Kiadó, 1995), 186.

93 The Correspondence of Ferenc Sziklay, Fond 158. OSZK Kt. These documents had landed in the bequest presumably by accident, as Sziklay become manager in the reorganized circle in Czechoslovakia. See also 'A Kazinczy-Társaság ujjáébredéséhez.' Kassai Hirlap, 1920. szeptember 28, (1920): 221.

94 Editorial, Felsömagyarország, January 13, 1898.; Kassai Hírlap, January 14, 1898.

95 Géza Gerlóczy, ed., A Kassai Kazinczy-Kör évkönyve 1898-1901 (Kassa: Vitéz A. könyv-, köés münyomdája, 1901). 
96 Béla Blanár, ed., A Kassai Kazinczy-Kör évkönyve 1901-1904 (Kassa: Kazinczy-kör, 1904). 25-9.

97 'Kassai Kazinczy-kör.' Editorial. Kultura 1, no. 13. (1911): 569.

98 The category 'Other' includes day-men and servants.

99 A Magyar Szent Korona országainak 1900. évi népszámlálása. 8. rész. Közszolgálati ágak és szabadfoglalkozások (Budapest: Magyar Kir. Központi Statisztikai Hivatal, 1906). 126.

100 László Sziklay, 'Brósz Jonathán.' A Szegedi Pedagógiai Föiskola Évkönyve, (Szeged, SZPF, 1957): 131-153.

101 Ethnic origins and affiliation are not considered here from the viewpoint of identity but as means of exclusion in historical interpretations.

102 Magyarország tiszti cím-és névtára - 17. évfolyam (Budapest: A M. Kir. Központi Statisztikai Hivatal, 1898).; Kassa sz. k. v. és Abaújtorna V. M. Czím És Lakásjegyzéke (Kassa: Koczányi Béla, 1906). All names were identified with the help of these city directories and registries.

103 Elena Mannová, 'Verejnost' verzus rodinný krb? Ženy v spolkoch na Slovensku v 19. storočí.' Človek a spoločnost' 9, no. 4. (2006): 37-48.

104 Lajos Tímár, Vidéki városlakók. Debrecen társadalma, 1920-1944 (Budapest: Magvető, 1993).

105 Kövér György, 'Egy biedermeier cipszer polgárcsalád életstratégiája', in Rendi társadalom - polgári társadalom 7. eds. Zs. Németh and Cs. Sasfi (Budapest: Csokonai Kiadó, 1997). 175-9.; Pál Koudela, 'A Piece of Late Modern Age History of Hungary through the Rombauer Family Tree. 1.' Prague Papers on the History of International Relations 19, no. 1 (2015): $28-45$.

106 Czoch, 'Kassa polgársága a 19. század első felében', 77.

107 Věra Olivova, The Doomed Democracy, Czechoslovakia in a Disrupted Europe 1914-1938. (London: Sidgwick and Jackson, 1972), 56.

108 Elena Mannová, 'Meštianstvo na Slovensku v 19. a 20. storočí ako predmet historického výskumu.' Historický časopis 45, no. 1. (1997): 85-90.

Open Access. This is an open-access article distributed under the terms of the Creative Commons Attribution 4.0 International License (https://creativecommons.org/licenses/by/4.0), which permits unrestricted use, distribution, and reproduction in any medium, provided the original author and source are credited, a link to the CC License is provided, and changes - if any - are indicated. (SID_1) 
